\title{
Interspinous Line: Relations with Other Landmarks (Xiphisternum, Umbilicus, Pubic Symphysis and Arcuate Line of Douglas) and Importance for Surgeons
}

\author{
Maulana M. Ansari, MBBS, MS (Gen. Surgery), PhD (Surgery)* \\ Ex-Professor of General Surgery, Department of Surgery, J. N. Medical College, Aligarh Muslim University, \\ Aligarh, UP, India \\ *Corresponding Author: Maulana M. Ansari, MBBS, MS (Gen. Surgery), PhD (Surgery), Ex- \\ Professor of General Surgery, Department of Surgery, J. N. Medical College, Aligarh Muslim University, \\ Aligarh, UP, India, Email: mma_amu@yahoo.com
}

\begin{abstract}
In addition to open surgery such as rectus abdominis flap harvest and stoma formation, anterior interspinous line joining two anterior superior iliac spines has also become an important surgical landmark during laparoscopic surgery including total extraperitoneal preperitoneal (TEPP) repair for inguinal hernia. Relations of interspinous line with four other surface landmarks (Xiphisternum, umbilicus, pubic symphysis, and arcuate line of Douglas) were studied during TEPP hernioplasty in Indian male population. Mean distances of the interspinous line from xiphisternum, umbilicus, pubic symphysis, and arcuate line were 23.82 \pm SD 2.49 (Range 19.5-29.0 cm), $9.17 \pm S D 1.83 \mathrm{~cm}$ (Range 5.25-13.4 cm), $6.79 \pm$ SD 1.67 (Range 1.1-9.25 $\mathrm{cm}$ ), and $3.71 \pm S D 2.32$ (Range, -1.5 to $9.5 \mathrm{~cm}$ ) respectively. Anterior interspinous line was found situated at $57.56 \%$ of umbilico-pubic distance, at $42.62 \%$ of pubo-umbilical distance, at $78.15 \%$ of xiphisterno-pupic distance, and at $22.28 \%$ of pubo-xiphisternal distance. Exact location of anterior interspinous line relative to other surface landmarks or vice versa may prove more useful in a number of clinical situations including in detection/quantification of fixed lower limb deformity, in diagnosis of Spigelian hernia, in siting of Lanz incision for appendicectomy or incision for stoma construction well above Arcuate line, in making incision for abdominoplasty/rectus abdominis myocutaneous flap harvest well above Arcuate line, in re-positioning of umbilicus after reconstructive/aesthetic surgery and in placement of middle port at or below arcuate line during TEPP hernioplasty. Validation of our results is recommended in Indian and Non-Indian populations by more research work with larger sample size in clinical settings.
\end{abstract}

Keywords: Interspinous line, spinous line, surface marking, umbilicus, xiphisternum, pubic symphysis, Arcuate line, TEPP hernioplasty, rectus abdominis flap, stoma formation;

Abbreviations: ASIS, anterior superior iliac spine; AISL, anterior interspinous line; AL, arcuate line of Douglas; U, umbilicus; Z, xiphisternum; PS, pubic symphysis; AISL-AL / AL-AISL, distance from anterior interspinous line to arcuate line; AISL-U / U-AISL, distance from anterior interspinous line to umbilicus; AISL-Z / Z-AISL, distance from anterior interspinous line to xiphisternum; AISL-PS / PS-AISL, distance from anterior interspinous line to pubic symphysis;

\section{INTRODUCTION}

Anterior interspinous line (AISL) is defined as the horizontal line joining the two anterior superior iliac spines. It has been used as an important reference point not only during clinical examinations such as for determining the angle of fixed abduction/adduction deformity of the lower limb under the Kothari's method [1] but also during planning of the rectus abdominis myocutaneous flap/ abdominoplasty [2-4] and stoma formation [5].
Anterior interspinous line is also important in hernia surgery, and it defines the lower boundary of the Spigelian hernia belt [6-8]. In view of its huge potential of use in surgery, the relationship of the anterior interspinous line with four other landmarks (3 external surface landmarks of umbilicus, xiphisternum and pubic symphysis as well as 1 internal landmark of the Arcuate line of Douglas) were studied during the laparoscopic total extraperitoneal preperitoneal (TEPP) hernia repair in patients with inguinal hernia. 


\section{Materials AND MethodS}

A prospective study was carried out in adult male patients (only ASA I and II grades of American Society of Anesthesiologists) with uncomplicated primary inguinal hernia who underwent laparoscopic total extraperitoneal preperitoneal (TEPP) hernia repair under informed consent and ethical clearance of Faculty of Medicine, Aligarh Muslim University. Study was conducted at Jawaharlal Nehru Medical College Hospital, Aligarh w.e.f. April, 2010 to November, 2016. Surgical approach with standard 3-midline-port and telescopic dissection was used in all patients, utilizing the same technique as reported earlier [9-14]. Selection/ inclusion/ exclusion criteria were also same. Relations of the anterior interspinous line with three external surface landmarks (Umbilicus, pubic symphysis, xiphisternum) and one internal landmark (Arcuate line of Douglas) were recorded. Body mass index (BMI) of the patients was calculated by the Deurenberg's formula [15]. Tips of anterior iliac spines (ASIS) were used to mark a horizontal line, the anterior interspinous line (AISL). Tip of the xiphisternum (X), lower border of the umbilicus (U) and upper border of the pubic symphysis (PS) were taken as the reference points to measure the Xiphisternumto- anterior interspinous line distance (X-AISL), umbilicus-to-anterior interspinous line distance (U-AISL) and pubic symphysis-anterior interspinous line (PS-AISL). To measure the arcuate line-anterior interspinous line distance (AL-AISL) was measured after percutaneous needle confirmation of the arcuate line (Fig. 1) [16].

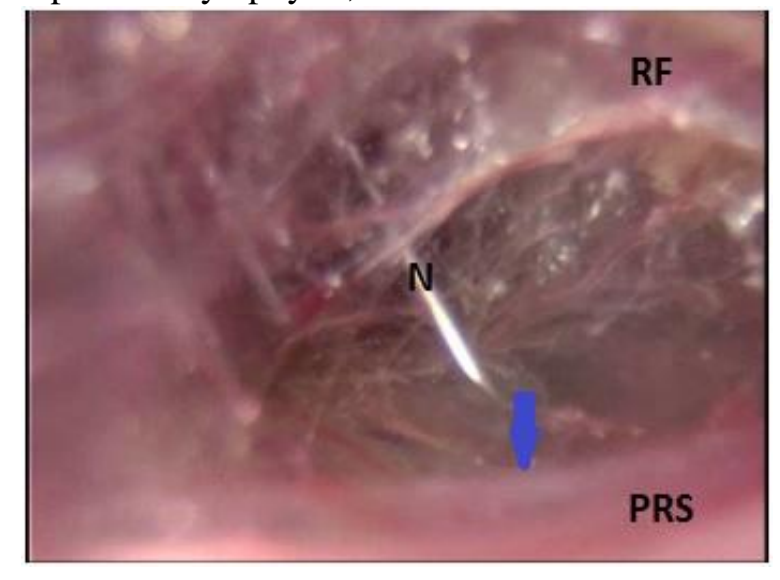

Figure 1: Percutaneous Needle Confirmation of Arcuate Line after Telescopic Dissection in the Posterior Rectus Canal: N, ordinary hypodermic needle inserted percutaneously at the level of arcuate line; RF, rectusial fascia covering the rectus abdominis muscle anteriorly; PRS, incomplete posterior rectus sheath; Arrow, indicates arcuate line; (Adapted with permission from Ansari, MM. A Study of Laparoscopic Surgical Anatomy of Infraumbilical Posterior Rectus Sheath, Fascia Transversalis \& Pre-Peritoneal Fat/Fascia during TEPP Mesh Hernioplasty for Inguinal Hernia. PhD (Surgery) Thesis 2016,Aligarh Muslim University, Aligarh, India)

\section{RESULTS}

A total of 60 adult male patients were studied during the successful laparoscopic total extraperitoneal preperitoneal (TEPP) hernia repair for the uncomplicated primary inguinal hernia in Indian population. Thirteen patients were excluded from the analysis due to absence of the arcuate line in them, and hence the present data analysis includes only 47 male patients. Mean age and BMI of the patients were $51.64 \pm$ SD16.42 (range 18-80) years and $22.54 \pm$ SD2.22 (range 19.3-31.2) $\mathrm{Kg} / \mathrm{m}^{2}$ respectively. Patients' occupation included farmer $(n=5)$, field worker $(n=4)$, manual labourer (20), office worker $(n=6)$, retired (8), and students (4).

\subsection{Location of Interspinous Line}

Mean distances of the interspinous line from the umbilicus, pubic symphysis, xiphisternum and arcuate line were $9.17 \pm$ SD $1.83 \mathrm{~cm}$ (Range 5.25-13.4 cm), $6.79 \pm$ SD 1.67 (Range 1.1-9.25 $\mathrm{cm}$ ), $23.82 \pm$ SD 2.49 (Range 19.5-29.0 cm), and $3.71 \pm$ SD 2.32 (Range, -1.5 to $9.5 \mathrm{~cm}$ ) respectively (Table 1). Anterior interspinous line (AISL) was found situated at about half of the umbilico-pubic distance, at about $1 / 3^{\text {rd }}$ of the of the pubo-umbilical distance, at about $3 / 4^{\text {th }}$ of the xiphisterno-pupic distance, and at $1 / 5^{\text {th }}$ of the pubo-xiphisternal distance (Table 2). 
Interspinous Line: Relations with Other Landmarks (Xiphisternum, Umbilicus, Pubic Symphysis and Arcuate Line of Douglas) and Importance for Surgeons

Table 1: Measurements of Anterior Interspinous Line in Patients $(N=47)$ with Incomplete Posterior Rectus Sheath with Arcuate Line $(N=54)^{a}$

\begin{tabular}{|c|c|c|c|c|c|}
\hline S.No. & Distance & N & Mean $(\mathbf{c m})$ & ${ }^{7}$ S.D. $(\mathbf{c m})$ & Range $(\mathbf{c m})$ \\
\hline 1. & ${ }^{1}$ U - PS & 47 & 15.93 & 1.47 & 11.5 to 18.5 \\
\hline 2. & ${ }^{2}$ AL-AISL & $54^{\text {a }}$ & 3.71 & 2.32 & -1.5 to 9.5 \\
\hline 3. & ${ }^{3}$ U - AISL & 47 & 9.11 & 1.86 & 5.25 to 13.4 \\
\hline 4. & ${ }^{4}$ AISL - PS & 47 & 6.82 & 1.76 & 20.5 to 29 \\
\hline 5. & ${ }^{5} \mathrm{Z}-$ AISL & 47 & 23.80 & 2.43 & 24 to 34 \\
\hline
\end{tabular}

ancludes contralateral sides of seven patients with bilateral inguinal hernias undergoing bilateral total extraperitoneal preperitoneal (TEPP) hernioplasty; ${ }^{1} U$ - PS, distance from centre of umbilicus (U) to upper border of pubic symphysis (PS); ${ }^{2}$ AL-AISL, distance from arcuate line (AL) to anterior interspinous line (AISL) between two anterior superior iliac spines; ${ }^{3} \mathrm{U}$ - AISL, distance from centre of umbilicus (U) to anterior interspinous line (AISL); ${ }^{4}$ AISL - PS, distance from anterior interspinous line (AISL) to upper border of pubic symphysis (PS); ${ }^{5} \mathrm{Z}$ - AISL, distance from lower border of xiphisternum (Z) to anterior interspinous line (AISL); ${ }^{6} \mathrm{Z}$ - PS, distance from lower border of xiphisternum (Z) to upper border of pubic symphysis (PS); ${ }^{7}$ S.D., standard deviation.

Table 2: Relative Position and Ratio of Interspinous Line to the Respective Surface Landmark Distances of the Body

\begin{tabular}{|l|c|c|c|c|}
\hline S. No. & $\begin{array}{c}\text { Distance of AISL to } \\
\text { Other Landmarks }\end{array}$ & $\begin{array}{c}\text { Distance Between } \\
\text { Other Body } \\
\text { Landmarks }\end{array}$ & $\begin{array}{c}\text { Location of }{ }^{\mathbf{9}} \text { ISL } \\
(\boldsymbol{\%})\end{array}$ & $\begin{array}{c}\text { Location of } \\
{ }^{\mathbf{9}} \text { ISL(Ratio) }\end{array}$ \\
\hline 1. & ${ }^{1} \mathbf{U}-$ AISL & ${ }^{5} \mathbf{U}-\mathbf{P S}$ & $57.56 \%$ & $1: 1.7$ \\
\hline 2. & ${ }^{\mathbf{2}}$ AISL - PS & ${ }^{\mathbf{6}} \mathbf{P S}-\mathbf{U}$ & $42.62 \%$ & $1: 2.3$ \\
\hline 3. & ${ }^{\mathbf{3}} \mathbf{Z}$ - AISL & ${ }^{7} \mathbf{Z}$ - PS & $78.15 \%$ & $1: 1.3$ \\
\hline 4. & ${ }^{4}$ AISL - Z & ${ }^{8}$ PS - Z & $22.28 \%$ & $1: 4.5$ \\
\hline
\end{tabular}

${ }^{1}$ U-ISL, distance from centre of umbilicus (U) to anterior interspinous line (AISL); ${ }^{2}$ AISL-PS, distance from anterior interspinous line (AISL) to upper border of pubic symphysis (PS); ${ }^{3} \mathrm{Z}$-AISL, distance from lower border of xiphisternum (Z) to anterior interspinous line (AISL);; ${ }^{4}$ AISL-Z, distance from anterior interspinous line (AISL) to lower border of xiphisternum (Z); ${ }^{5} \mathrm{U}-\mathrm{PS}$, distance from centre of umbilicus (U) to upper border of pubic symphysis (PS); ${ }^{6} \mathrm{PS}-\mathrm{U}$, distance from upper border of pubic symphysis (PS) to centre of umbilicus (U); ${ }^{7}$ Z-PS, distance from lower border of xiphisternum (Z) to centre of umbilicus (U); ${ }^{8} \mathrm{PS}-\mathrm{Z}$, distance from upper border of pubic symphysis (PS) to lower border of xiphisternum (Z); ${ }^{9} \mathrm{AISL}$, anterior interspinous line;

With respect to the anterior interspinous line, present study documented 25 locations of the arcuate line at $-1.5 \mathrm{~cm}(\mathrm{n}=1), 1.25 \mathrm{~cm}(\mathrm{n}=5), 1.5$ $\mathrm{cm}(\mathrm{n}=2), 1.75 \mathrm{~cm}(\mathrm{n}=3), 1.9 \mathrm{~cm}(\mathrm{n}=1), 2 \mathrm{~cm}$ $(\mathrm{n}=3), 2.25 \mathrm{~cm}(\mathrm{n}=4), 2.5 \mathrm{~cm}(\mathrm{n}=3), 2.75 \mathrm{~cm}$ $(\mathrm{n}=5), 2.8 \mathrm{~cm}(\mathrm{n}=2), 3 \mathrm{~cm}(\mathrm{n}=1), 3.5 \mathrm{~cm}(\mathrm{n}=4)$, $3.75 \mathrm{~cm}(\mathrm{n}=1), 4 \mathrm{~cm}(\mathrm{n}=2), 4.5 \mathrm{~cm}(\mathrm{n}=1), 5 \mathrm{~cm}$ $(\mathrm{n}=4), 5.5 \mathrm{~cm}(\mathrm{n}=2), 6 \mathrm{~cm}(\mathrm{n}=2), 6.25 \mathrm{~cm}(\mathrm{n}=1)$, $6.5 \mathrm{~cm}(\mathrm{n}=2), 7.5 \mathrm{~cm}(\mathrm{n}=2), 8 \mathrm{~cm}(\mathrm{n}=1), 8.5 \mathrm{~cm}$ $(n=1), 9 \mathrm{~cm}(n=1)$ and $9.5 \mathrm{~cm}(n=1)$ from the anterior interspinous line, with a mean of $3.71 \pm 2.32 \mathrm{~cm}$ (range -1.5 to $9.5 \mathrm{~cm}$ ).

\subsection{Comparison of Interspinous Line Level on Two Sides of Body}

In addition to the ipsilateral measurement of AISL-AL (anterior interspinous line to arcuate line of Douglas) distance in 47 patients; AISLAL distance was also measured on the contralateral side in 7 out of 8 patients with bilateral inguinal hernia who underwent bilateral TEPP hernioplasty (one patient with absent arcuate line on contralateral side was excluded). No significant difference was found in the average AISL-AL distance on the two sides of the body (Table 3).

Table 3: Bilateral Measurements of AISL-AL (Distance from Anterior interspinous line to Arcuate Line) in Adult Male Patients $(N=47)$ who underwent TEPP Hernioplasty

\begin{tabular}{|c|c|c|c|c|c|c|}
\hline S. No. & $\begin{array}{c}* \text { AISL-AL Distance } \\
\text { One Side } \\
(\text { Mean } \pm \text { SD } * *) \\
(\text { Range })(\mathrm{cm})(\mathbf{N})\end{array}$ & $\begin{array}{c}* \text { AISL-AL Distance } \\
\text { Contralateral Side } \\
(\text { Mean } \pm \text { SD } *) \\
(\text { Range })(\mathrm{cm})(\mathbf{N})\end{array}$ & C.I.D** & t-value ${ }^{\text {II }}$ & Sig. & p-value \\
\hline 1. & $\begin{array}{c}3.69 \pm 2.49 \\
(-1.5 \text { to } 9.5) \\
(\mathbf{N}=\mathbf{4 7})\end{array}$ & $\begin{array}{c}4.57 \pm 1.03 \\
(3.5-6.25) \\
(\mathbf{N}=7)\end{array}$ & $\begin{array}{c}-1.0450 \\
\text { to } \\
2.8050\end{array}$ & 0.917 & 0.3632 & $>0.05$ \\
\hline
\end{tabular}

*AISL-AL, distance from anterior interspinous line (AISL) to arcuate line (AL); **SD, standard deviation; **C.I.D, 95\% confidence interval of difference; ${ }^{\mathbb{T}} \mathrm{t}$-value, Student t-test; 
Interspinous Line: Relations with Other Landmarks (Xiphisternum, Umbilicus, Pubic Symphysis and Arcuate Line of Douglas) and Importance for Surgeons

\subsection{Symmetry on Two Sides of Body in Patients with Bilateral Hernia}

In 1 out of 8 patients who underwent bilateral TEPP hernia repair, the arcuate line was found absent on both sides of the body, and the AISLAL distance could be measured in only 7 patients with bilateral hernia. However, in 2 out of these 7 cases, the arcuate line was found absent on the first side (ipsilateral) operated and hence, AISL-AL measurements were done on 5 ipsilateral sides and 7 contralateral sides in patients with bilateral hernia. In 2 out of 5 patients with bilateral presence of the arcuate line, AISL-AL distance was almost symmetrical while in the remaining 3 patients, AISL-AL distance was asymmetrical with difference ranging from 1.25 to $3.75 \mathrm{~cm}$. However, the average AISL-AL distance on the two sides of the body was not significantly different (Table 4).

Table 4: Measurements of AISL-AL Distance (From Anterior Interspinous Line to Arcuate Line) in Patients $(N=8)$ undergoing Bilateral TEPP Hernioplasty

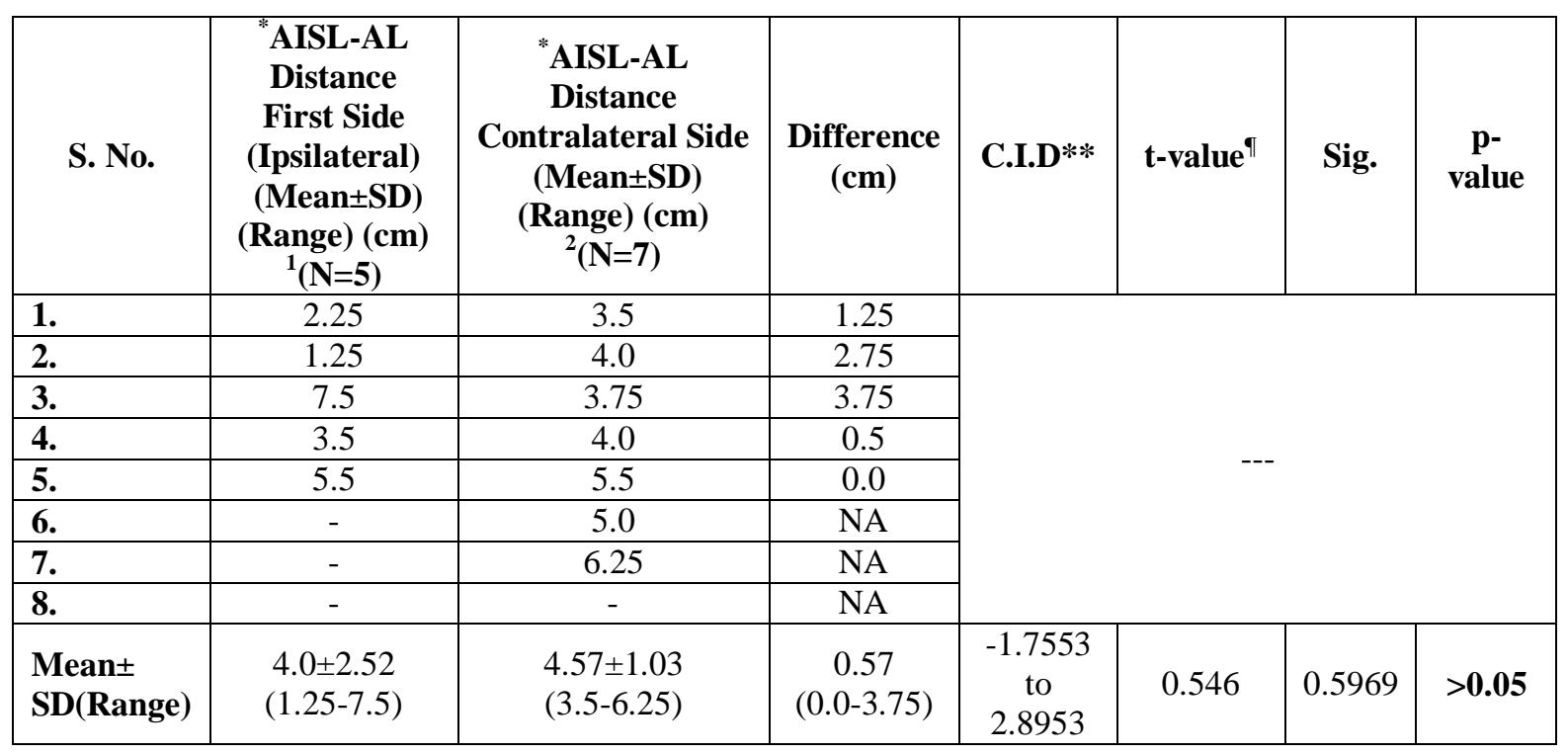

*AISL-AL, distance from anterior interspinous line (AISL) to arcuate line (AL); ${ }^{1}(\mathrm{~N}=5)$, number of patients having arcuate line of Douglas, i.e., 3 out of 8 patients with absent arcuate line were excluded; ${ }^{2}(\mathrm{~N}=7)$, number of patients having arcuate line of Douglas on contralateral side, i.e., 1 out of 8 patients with absence of arcuate line on the contralateral side also was excluded;

\subsection{Correlation with Demographic Characteristics}

Age and occupation of our patients did not affect significantly the distance from the arcuate line to the interspinous line (AL-AISL), the distance from xiphisternum to anterior interspinous line (Z-AISL) and the distance from pubic symphysis to anterior interspinous line (PS-AISL) (p >0.05) (Table 5). Pearson

Table 5: Various Distances from Anterior Interspinous Line in Three Age Groups of Patients who underwent Laparoscopic Total Extraperitoneal Preperitoneal (TEPP) Hernioplasty $(N=47)$

\begin{tabular}{|c|c|c|c|c|c|c|c|}
\hline \multirow[b]{2}{*}{$\begin{array}{l}\text { S. } \\
\text { No. }\end{array}$} & \multirow[b]{2}{*}{ Distance } & \multicolumn{3}{|c|}{ Age Groups (Years) } & \multirow{2}{*}{$\begin{array}{c}{ }^{\mathbb{T}} \mathbf{F}- \\
\text { value }\end{array}$} & \multirow{2}{*}{$\begin{array}{l}{ }^{\ddagger} \text { Sig. } \\
\text { (2- } \\
\text { tailed) }\end{array}$} & \multirow[b]{2}{*}{$\begin{array}{c}\text { p- } \\
\text { value }\end{array}$} \\
\hline & & $\begin{array}{l}18-40 \\
(n=14)\end{array}$ & $\begin{array}{l}41-60 \\
(n=19)\end{array}$ & $\begin{array}{l}61-80 \\
(n=14)\end{array}$ & & & \\
\hline 1. & $\begin{array}{c}{ }^{\mathbf{1}} \mathbf{A L}-\mathbf{A I S L} \\
(\mathrm{Mean} \pm \mathrm{SD}) \\
\text { (Range) }\end{array}$ & $\begin{array}{l}3.75 \pm 2.47 \\
(1.25-9.5)\end{array}$ & $\begin{array}{c}3.79 \pm 2.67 \\
(-1.5 \text { to } 9.0)\end{array}$ & $\begin{array}{l}3.50 \pm 2.45 \\
(1.25-7.5)\end{array}$ & $\begin{array}{c}F_{244}= \\
0.057\end{array}$ & 0.944 & $>0.05$ \\
\hline 2. & $\begin{array}{c}{ }^{2} \mathbf{U}-\mathbf{A I S L} \\
(\mathrm{Mean} \pm \mathrm{SD}) \\
\text { (Range) }\end{array}$ & $\begin{array}{c}3.93 \pm 1.81 \\
(7.0-13.0)\end{array}$ & $\begin{array}{c}9.26 \pm 1.47 \\
(6.75-12.0)\end{array}$ & $\begin{array}{c}9.09 \pm 2.43 \\
(5.25-13.4)\end{array}$ & $\begin{array}{l}F_{244}= \\
37.811\end{array}$ & 0.000 & $<0.001$ \\
\hline 3. & ${ }^{3}$ Z-AISL & $23.43 \pm 2.52$ & $23.82 \pm 2.32$ & $24.14 \pm 2.61$ & $F_{244}=$ & 0.749 & $>0.05$ \\
\hline
\end{tabular}

Correlations were also insignificant statistically $(\mathrm{p}>0.05)$. However, the mean distance from umbilicus to anterior interspinous line (U-AISL) in the younger age group of 18-40 years was significantly lower $(p<0.001)$ than those of middle age group (41-60 years ) and elderly age group (61-80 years) both of which were not different statistically from each other $(\mathrm{p}>0.05)$ (Table 5). 
Interspinous Line: Relations with Other Landmarks (Xiphisternum, Umbilicus, Pubic Symphysis and Arcuate Line of Douglas) and Importance for Surgeons

\begin{tabular}{|c|c|c|c|c|c|c|c|}
\hline & $\begin{array}{c}\text { (Mean } \pm \text { SD) } \\
\text { (Range) }\end{array}$ & $(20.5-29.0)$ & $(21.0-29.0)$ & $(21.25-28.8)$ & 0.291 & & \\
\hline 4. & $\begin{array}{c}{ }^{4} \text { PS-AISL } \\
(\text { Mean } \pm \text { SD) } \\
(\text { Range) }\end{array}$ & $\begin{array}{c}7.10 \pm 1.49 \\
(5.0-9.25)\end{array}$ & $\begin{array}{c}6.87 \pm 1.37 \\
(4.0-9.0)\end{array}$ & $\begin{array}{c}6.82 \pm 1.76 \\
(1.1-9.25)\end{array}$ & $\begin{array}{c}\mathrm{F}_{244}= \\
0.417\end{array}$ & 0.661 & $>0.05$ \\
\hline
\end{tabular}

${ }^{1} \mathrm{AL}-\mathrm{AISL}$, distance from arcuate line (AL) to anterior interspinous line (AISL); ${ }^{2} \mathrm{U}-\mathrm{AISL}$, distance from centre of umbilicus to anterior interspinous line (AISL); ${ }^{3} \mathrm{Z}$-AISL, distance from lower border of xiphisternum (Z) to anterior interspinous line (AISL); ${ }^{4} \mathrm{PS}$-AISL, distance from upper border of pubic symphysis to anterior interspinous line (AISL); ${ }^{\mathrm{I}} \mathrm{F}$-value, Analysis of variance (ANOVA) value; ${ }^{\ddagger}$ Sig., significance;

BMI of the patients did not affect significantly the distance from the umbilicus to anterior interspinous line (U-AISL) and the distance from pubic symphysis to anterior interspinous line (PS-AISL) ( $\mathrm{p}>0.05)$ (Table 6). However, patients' BMI affected significantly the distance from the arcuate line to the interspinous line

Table 6: Various Distances from Anterior Interspinous Line in Two BMI Groups of Patients who underwent Laparoscopic Total Extraperitoneal Preperitoneal (TEPP) Hernioplasty $(N=47)$

\begin{tabular}{|c|c|c|c|c|c|c|c|}
\hline \multirow{2}{*}{$\begin{array}{l}\text { S. } \\
\text { No. }\end{array}$} & \multirow{2}{*}{ Distance } & \multicolumn{2}{|c|}{ BMI Groups } & \multirow{2}{*}{${ }^{\pi}$ C.I.D } & \multirow{2}{*}{$\begin{array}{c}{ }^{\$_{\text {t- }}} \\
\text { value }\end{array}$} & \multirow{2}{*}{$\begin{array}{c}\text { Sig. } \\
\text { (2-tailed) }\end{array}$} & \multirow{2}{*}{$\begin{array}{c}\text { p- } \\
\text { value }\end{array}$} \\
\hline & & *Normal BMI & **High BMI & & & & \\
\hline 1. & $\begin{array}{c}{ }^{1} \mathbf{A L}-\mathbf{A I S L} \\
(\text { Mean } \pm \text { SD) } \\
\text { (Range) }\end{array}$ & $\begin{array}{c}3.34 \pm 2.15 \\
(-1.5 \text { to } 8.0)\end{array}$ & $\begin{array}{c}7.44 \pm 3.15 \\
(2.75 \text { to } 9.5)\end{array}$ & $\begin{array}{l}-6.4485 \\
\text { to } \\
-1.7515\end{array}$ & 3.5161 & 0.0010 & $<0.01$ \\
\hline 2. & $\begin{array}{c}{ }^{\mathbf{2}} \mathbf{U}-\mathbf{A I S L} \\
(\mathrm{Mean} \pm \mathrm{SD}) \\
(\text { Range })\end{array}$ & $\begin{array}{c}9.02 \pm 1.72 \\
(6.5-13.4)\end{array}$ & $\begin{array}{c}10.06 \pm 3.22 \\
(5.25-12.0)\end{array}$ & $\begin{array}{c}-2.9963 \\
\text { to } \\
0.9163\end{array}$ & 1.0707 & 0.2900 & $>0.05$ \\
\hline 3. & $\begin{array}{c}{ }^{3} \mathbf{Z} \text {-AISL } \\
(\text { Mean } \pm \text { SD) } \\
\text { (Range) }\end{array}$ & $\begin{array}{c}23.56 \pm 2.23 \\
(20.5-29)\end{array}$ & $\begin{array}{l}26.31 \pm 3.45 \\
(21.25-29)\end{array}$ & $\begin{array}{c}-5.2045 \\
\text { to } \\
-0.2955\end{array}$ & 2.2566 & 0.0289 & $<0.05$ \\
\hline 4. & $\begin{array}{c}{ }^{4} \text { PS-AISL } \\
(\text { Mean } \pm \text { SD }) \\
(\text { Range })\end{array}$ & $\begin{array}{c}6.88 \pm 1.77 \\
(1.1-9.25)\end{array}$ & $\begin{array}{c}6.19 \pm 1.77 \\
(5.0-8.75)\end{array}$ & $\begin{array}{c}-1.1735 \\
\text { to } \\
2.5535\end{array}$ & 0.7457 & 0.4597 & $>0.05$ \\
\hline
\end{tabular}

\section{DISCUSSION}

Anterior interspinous line (AISL) is commonly utilized in the assessment of the arcuate line position which is commonly reported to be $\sim 2$ $\mathrm{cm}$ superior to the anterior interspinous line $[17,18]$, although in some older reports, the two coincided in majority of their subjects $(>70 \%)$, i.e., the arcuate line was situated at the level of the anterior interspinous plane $[19,20]$. Position of the arcuate line (AL) with respect to the anterior interspinous line (AISL) is reported to be highly variable and debatable [21]. The present study also documented 25 locations of the arcuate line with respect to the anterior interspinous line, ranging from $-1.5 \mathrm{~cm}$ (inferior to AISL) to $9.5 \mathrm{~cm}$ (superior to the AISL). Moreover, average location of arcuate line with respect to the anterior interspinous line $(3.7 \pm 2.3$ $\mathrm{cm})$ was found substantially higher as compared to the recent reports of Cunningham et al [17] and Loukas et al [18] (Table 7) and much higher than those reported in the older studies $[19,20]$. These observations may possibly be a reflection of geographical \&/or racial variation
(AL-AISL) $(\mathrm{p}<0.01)$ and the distance from xiphisternum to anterior interspinous line (ZAISL) ( $\mathrm{p}<0.05$ ) (Table 6), both of them being much higher in the overweight/obese patient $\left(\mathrm{BMI}>25 \mathrm{Kg} / \mathrm{m}^{2}\right)$ as compared to that observed in patients with normal BMI $\left(<25 \mathrm{Kg} / \mathrm{m}^{2}\right)$. 
The AL-AISL distance (from arcuate line to interspinous line) was significantly much more in patients with high BMI $\left(>25 \mathrm{Kg} / \mathrm{m}^{2}\right)$ as compared to that observed in patients with normal BMI $\left(<25 \mathrm{Kg} / \mathrm{m}^{2}\right)$, indicating a higher position of the arcuate line in overweight/obese patients. Our observation is in full agreement with those of Cunningham and colleagues (2004) who emphasized that "Knowledge of this trend may be useful on a case-by-case basis, allowing the surgeon to err on the appropriate side average-body habitus" [17].

Anterior superior iliac spine (ASIS) is easily palpable in majority of people except the obese persons [23]. In the elderly age group, major integumentary system changes occur which include the loss of subcutaneous fat, the atrophy of epidermis, the stiffening of dermal collagen, and the calcification of elastin [24], and the epidermal growth slows down with resultant decrease in contact areas between the epidermis and the dermis and easy separation of them during clinical manoeuvres of palpation of the bony landmarks like the anterior superior iliac spines (ASIS) as has been documented in relation to the posterior superior iliac spines [25].

The two ASIS are at the same level in normal healthy persons, but not at the same level in presence of lower limb deformity or pelvic torsion [23]. Thus the anterior interspinous line (AISL), the transverse line joining the two ASIS, is used to detect the fixed bony deformity [1]. In the method of decompensation for detection of the fixed abduction deformity, abduction of the affected limb is continued till the anterior interspinous line becomes horizontal and at right angle to the long axis of the body. In this way, the 'concealed' deformity becomes 'revealed' and the deformity is measured by the angle formed between the horizontal anterior interspinous line and vertical long axis of the lower limb, which is called the angle of the fixed abduction deformity [1]. In Kothari's method, the angle formed between the anterior interspinous line and the horizontal line drawn from the sound side ASIS is measured; this angle of fixed abduction deformity is formed at the sound side 'below' the horizontal line. In a similar fashion, fixed adduction deformity of the lower limb is also ascertained [1].

The anterior interspinous line forms the lower boundary of the 'Spigelian Hernia Belt or Zone' in the widest part of the Spigelian fascia, abdominal flat muscle aponeurosis that extends between the semilunar line and lateral border of rectus abdominis,; this hernia prone zone extends vertically upwards for about $6 \mathrm{~cm}$ and bounded superiorly by the transverse umbilical line (Fig 2) [7, 8, 26]. The 'hernia prone area' has been more refined by some authors in terms of its upper boundary formed by the spinoumbilical line of Monro, the line joining the right ASIS to the umbilicus, on the right side of the body, and by the spino-umbilical line of Monro-Richter joining the left ASIS to the umbilicus on the left side (Fig 3) [6]. About 85$90 \%$ of the Spigelian hernias are known to occur in the Spigelian Belt, although preoperative clinical diagnosis is made only in $50 \%$ of the cases by the presence of a small reducible parietal swelling with positive cough impulse in the target area and reducing in the lying down posture, or by the presence of a painful tender irreducible lump (Fig 4); sometimes it presents as the 'Masked' hernia of Macready [8].

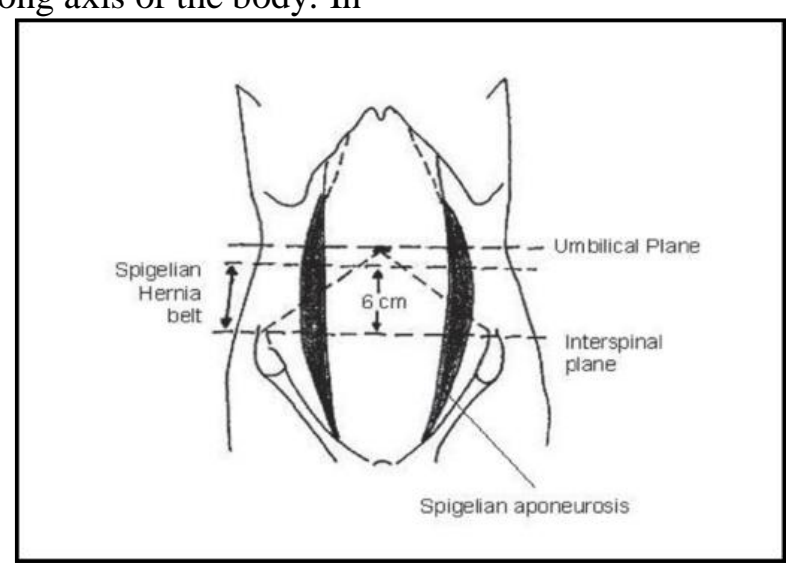

Figure 2: Classical Spigelian Hernia Belt or Zone: The Anterior Spinous Line is also known as 'Interspinal Line' as depicted in the diagram here. (Adapted under Open Access Creative Commons Attribution License) from Mittal T, Kumar V, Khullar R, et al. Diagnosis and Management of Spigelian Hernia: A Review of Literature and Our Experience. J Minim Access Surg. 2008 Oct-Dec; 4(4): 95-98.) (Accessed: July 12, 2017) 


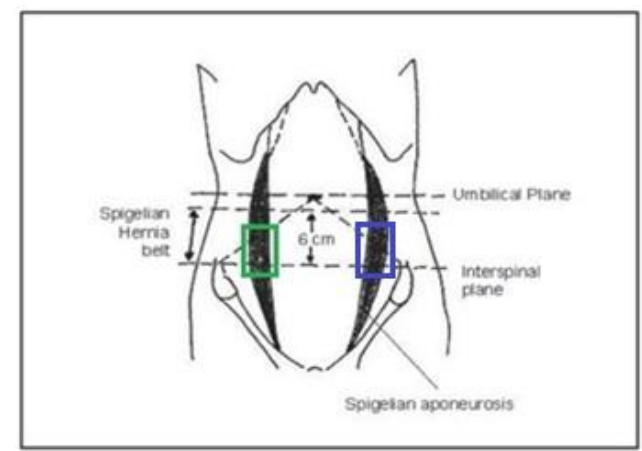

Figure 3: Modified Spigelian Hernia Belt: On right side, Spigelian Belt is represented by Area of Spigelian Aponeurosis within Green Rectangle, which is bounded inferiorly by Interspinal or Interspinous Line joining two anterior superior iliac spines \& superiorly by the Right Spino-umbilical Line of Monro; On left side, Spigelian Belt is represented by the Area of Spigelian Aponeurosis within the Blue Rectangle, which is bounded inferiorly by the Interspinal or Interspinous Line joining two anterior superior iliac spines and superiorly by Left Spino-umbilical Line of Monro-Richter; (Adapted with slight modification under Open Access Creative Commons Attribution License) from Mittal T, Kumar V, Khullar R, et al. Diagnosis and Management of Spigelian Hernia: A Review of Literature and Our Experience. J Minim Access Surg.2008 OctDec; 4(4): 95-98.) (Accessed: July 12, 2017)

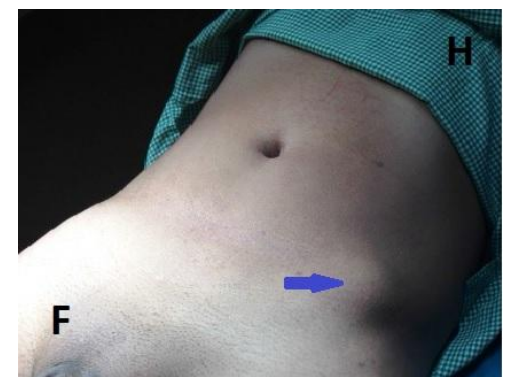

Figure 4: Clinical Photograph of Spigelian Hernia: H, head end of the patient; F, foot end of the patient; Arrow, indicates Spigelian hernia on the left side; (Adapted with slight modification under Open Access Creative Commons Attribution License) From Goyal S, Singla S. Spigelian Hernia-Diagnostic Dilemma: Case Report with Review. Open Access Library Journal 2014; 1: e661. (http://dx.doi.org /10.4236/ oalib.1100661) (Accessed: July 12, 2017)

Exact location of the anterior interspinous line relative to other surface landmarks may prove more useful in planning various surgical procedures. The point of Lanz lies at the junction of right and middle third of the anterior interspinous line (Fig 5), and the Point of Sonnenberg lies at the junction of the anterior interspinous line and the right Spigelian semilunar line, i.e., the lateral margin of the right rectus abdominis muscle (Fig 6); both these topographical points indicate the position of the appendix vermiformis, especially in its pelvic position [27], and help in placement of a more aesthetic Lanz horizontal incision for the appendicectomy [28-30].

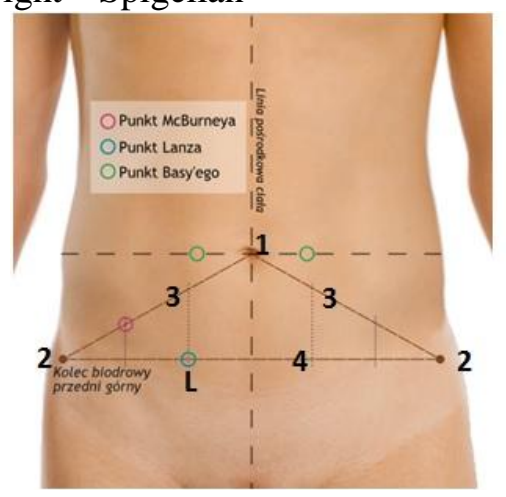

Figure 5: Point of Lanz (L) situated at the junction of right and middle 1/3 rd of the Interspinous Line (4); 1, indicates umbilicus; 2 , indicates right and left anterior superior iliac spines; 3 , indicates spino-umbilical line. (Adapted with slight modification under Open Access (Creative Commons 3.0. Attribution-ShareAlike (CC BYSA 3.0) from M•Komorniczak -talk-, polish wikipedist. Illustration by: Michat Komorniczak, Oct 16, 2009. (Accessed: July 12, 2017) 


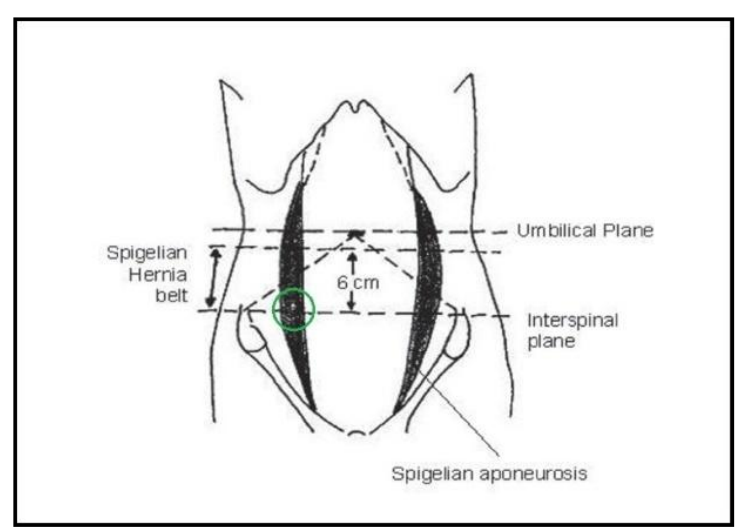

Figure 6: Point of Sonnenberg (Green Circle) situated at the junction of the Interspinous/Interspinal line and the right Spigelian line/aponeurosis at the lateral border of the rectus abdominis muscle; (Adapted with slight modification under Open Access (CreativeCommons 3.0. Attribution-ShareAlike (CC BY-SA 3.0) from M•Komorniczak -talk-, polish wikipedist. Illustration by :Michat Komorniczak, Oct 16, 2009. (Accessed: July 12, 2017)

Taking the anterior interspinous line as one of the three criteria, the vascular blood supply of the anterior abdominal wall was classified into 3 zones especially for the purpose of the abdominoplasty (Fig. 7) [31]. The three Huger's vascular zones of the anterior abdominal wall were first described in 1979 by Huger [31], and are regarded as important prognostic considerations in abdominoplasty [32-36]. Zone I (mid-abdomen) is the area from xyphoid to pubis bounded laterally by the lateral margin of the rectus muscles and inferiorly by the anterior interspinous line, which is supplied mainly by the superior epigastric vessels, and supplemented by the inferior epigastric vessels from below and secondary vessels from the Zone III (lateral abdomen); Zone II (lower abdomen) is the area of the lower abdomen from the anterior interspinous line to the pubis and inguinal creases, which is supplied mainly by the deep inferior epigastric artery arising from the external iliac artery and also by the superficial branches of the femoral artery including the superficial epigastric artery, the superficial external pudendal artery and the superficial circumflex iliac artery; Zone III (lateral abdomen) comprises the area on each side of the abdomen lateral to the Zone I (midabdomen) and is bounded inferiorly by the anterior interspinous line (Fig 7); the Zone III (lateral abdomen) is supplied by the intercostal, subcostal, and lumbar arteries that are branches from the aorta [4].

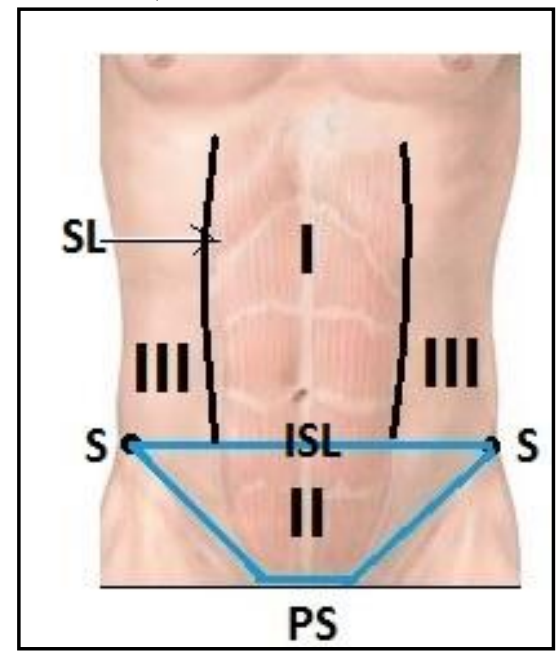

Figure 7: Huger's Vascular Zones of Abdomen: SL, Spigelian semilunar line, i.e., lateral border of rectus abdominis muscle; S, anterior superior iliac spine; ISL, anterior interspinous/Interspinal line; PS, pubic symphysis; I, mid-abdomen (Zone 1) bounded by the Spigelian semilunar line on either side and by the anterior interspinous line; II, lower abdomen (Zone 2) bounded superiorly by the anterior interspinous line, inferiorly by pubic symphysis and infero-laterally by the inguinal crease on either side; III, paired lateral abdomen (Zone 2) bounded medially by Spigelian semilunar line and inferiorly by anterior interspinous line; 
The umbilicus is a prominent midline anatomical landmark located normally at the level of the intervertebral disc between the third and fourth lumbar vertebrae (L3 \& L4); however, this anatomical landmark is lower in children, obese or in those with a pendulous abdomen [37]. The bifurcation of the abdominal aorta lies $2 \mathrm{~cm}$ (a little less than an inch) distal to the umbilicus. The anterior interspinous line is normally located at the level of the fifth lumbar vertebra (Fig. 8) [37,38]; however some authorities documented its level at the sacral promontory (Fig. 9) [39,40]. In the current year of 2017, Dudukovic and associates strongly emphasized that the best prediction of the position of the umbilicus was based on the distance from the umbilicus to the anterior interspinous line using a specific regressive mathematical equation, especially for the correct positioning of the umbilicus in reconstructive and aesthetic procedures in which the original location of umbilicus gets affected by the surgical procedure [41].
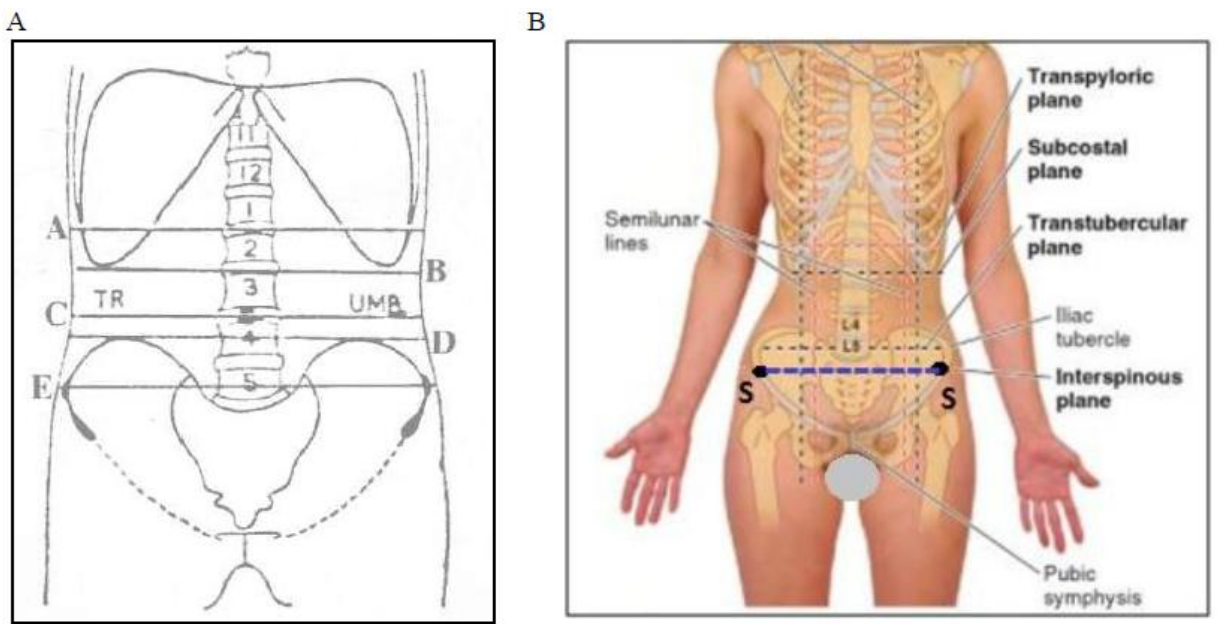

Figure 8: Vertebral Level of Anterior Interspinous Line: Both A \& B illustrations show that the anterior interspinous line has a vertebral level at the fifth lumbar vertebra (L5); E, anterior interspinous line; D, intercrestal line; $\mathbf{3}$ and $\mathbf{C}$, trans-umbilical line; $\mathbf{A}$, transpyloric line; $\mathbf{B}$, subcostal line; $\mathbf{S}$, anterior superior iliac spine; (A, Adapted with slight modification from Medscape (http://www.medscape.com) and Cox WA. Traumatic injuries of the organs of the abdominal cavity: adult and pediatric. April 2012; pp 1-202. (https:// forensicmd. files.wordpress.com/2012/04/traumatic-injuries-of-the-organs-of-the-abdominal-cavity-adult-and-pediatric.pdf ; B, Adapted with slight modification from Moore KL, Daily AF, Agur AMR (eds.) Clinically Oriented Anatomy. $7^{\text {th }}$ Edition, Chapter 2, Philadelphia: Wolters Kluwer, 2014, pp 181-325.)

A

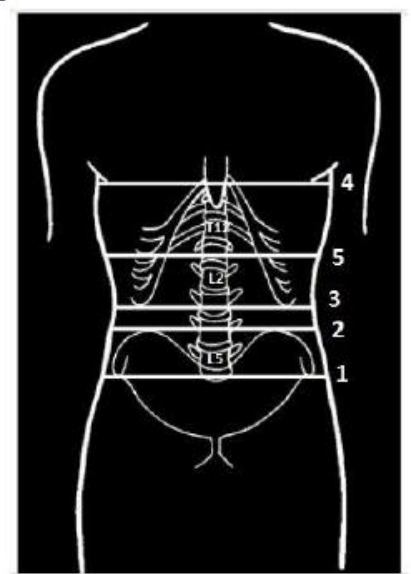

B

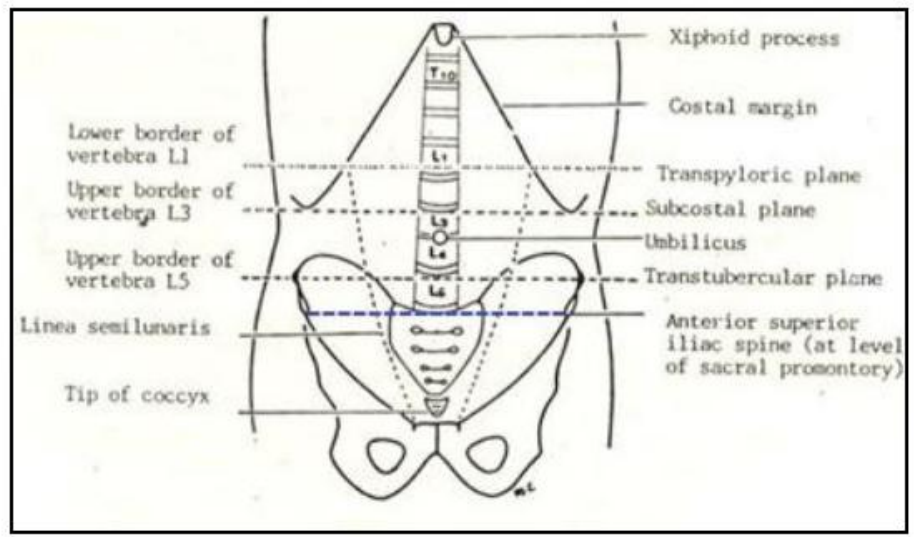

Figure 9: Vertebral Level of Anterior Interspinous Line: Both A \& B illustrations show that the anterior interspinous line has a vertebral level at the sacral promontory; 1and Blue Line, anterior interspinous line; 2 , intercrestal line; 3, trans-umbilical line; 4, transpyloric line; 5, subcostal line; (A, Adapted with slight modification from Jaroslav Kos, Jiri Hert, and Jaroslava Hladikaova (eds.) Survey of Topographical Anatomy .Chapter 4, Prague: Karolinum Press, 2014, pp 69-84.;B, Adapted with slight modification from Chaurasia BD. Anterior Abdominal Wall. Slide Share Website (https://www.slideshare.net/jeffarian/anterior-abdominal-wallbd-churasia) (Accessed July 12, 2017) 
For preoperative appropriate siting of an intestinal stoma, there is no fixed anatomical reference point, and a stoma construction below the Arcuate line of Douglas, the free inferior border of the incomplete posterior rectus sheath, may be a contributing factor to later parastomal herniation [5]. Anterior interspinous line is often used as an anatomic landmark to mark the level of the Arcuate line of Douglas so that the stoma may be sited well above the Arcuate line in order to pre-empt the risk of postoperative parastomal herniation [5]. Al-Momani and associates (2014) strongly recommended that the stoma should be sited at least $4 \mathrm{~cm}$ above the anterior interspinous line so that the stoma is situated about $2 \mathrm{~cm}$ above the Arcuate line. Cunningham et al [17] and Loukas et al [18] had reported earlier the AISL-AL distance (from anterior interspinous line to arcuate line) of $1.8 \pm 1.7 \mathrm{~cm}$ and $2.1 \pm 2.3 \mathrm{~cm}$ respectively, which goes in favour of the contention of Al-Momani and colleagues [5]. However, the present study recorded the mean AISL-AL distance of $3.7 \pm 2.3$ $\mathrm{cm}$ albeit with wide variations (range -1.5 to 9.5 $\mathrm{cm})$, which is substantially higher $(\mathrm{p}<0.001)$ than that reported earlier and which may reflect geographical or racial variation. In 2010, Mwachaka et al [42] has reported even gender variation in the incidence of the arcuate line. Therefore, it may not be an optimal criterion for stoma siting as was also evident from a high incidence the unsatisfactory siting of the stoma in $36-55 \%$ of patients in different categories of Al-Momani's series [5]. This may be a reflection of two factors, viz., firstly, the arcuate line position is reported to be highly variable [10-12, 17,18,21,22, 42-46], being significantly higher in the overweight/obese individuals [12, 17, 43, 47]; secondly, the level of the anterior interspinous line may also vary depending upon the body habitus and gender of the individual. Present study is limited by absence of female patients.

In addition to stoma construction, the AISL-AL distance may also be helpful to locate more accurately the arcuate line in the preoperative marking of the arcuate line that may facilitate preoperative planning of a rectus abdominis myocutaneous flap harvest not only for choosing the site for incision for raising the flap but also closing the resultant abdominal defect after the flap harvest [17, 43, 48,4 9]. Way back in 1998, Zenn and May eloquently described the method of dividing the rectus muscle at or near the level of the arcuate line so that the anterior rectus fascia of the inferior portion of the muscle can be sutured to the arcuate line [50], and this technique is still followed [17]. .

During the laparoscopic total extraperitoneal (TEPP) hernioplasty, the arcuate line is one of the three essential important surgical landmarks during the early phase of medial dissection in the posterior rectus canal [51-56], because the preperitoneal space is created just below the traditional arcuate line. The anterior interspinous line is one of the important landmarks to ascertain the average position of the Arcuate line for the preoperative planning and port placement, especially the middle port at or below the level of the arcuate line in the 3port-in-midline technique for TEPP hernioplasty. Caution needs to be exercised, atleast in Indian population because the present study recorded substantially higher arcuate line with respect to the anterior interspinous line (mean $3.7 \pm 2.3 \mathrm{~cm}$ ) as compared to that of about $2 \mathrm{~cm}$ reported in the previous studies from other countries [5,17,18]. Moreover, more research work is required in Indian and Non-Indian populations to validate the present observations, especially with larger sample size under the clinical settings.

\section{CONCLUSiON}

Mean distances of the anterior interspinous line from xiphisternum, umbilicus, pubic symphysis, and arcuate line in our Indian male patients were $23.82 \pm$ SD 2.49 (Range 19.5-29.0 cm), $9.17 \pm$ SD $1.83 \mathrm{~cm}$ (Range 5.25-13.4 cm), $6.79 \pm$ SD 1.67 (Range 1.1-9.25 cm), and 3.71 \pm SD 2.32 (Range, -1.5 to $9.5 \mathrm{~cm}$ ) respectively. Anterior interspinous line was found situated at $57.56 \%$ of the umbilico-pubic distance, at $42.62 \%$ of the of the pubo-umbilical distance, at $78.15 \%$ of the xiphisterno-pupic distance, and at $22.28 \%$ of the pubo-xiphisternal distance. Exact location of anterior interspinous line relative to other surface landmarks or vice versa may prove more useful in a number of clinical situations including in detection/quantification of fixed lower limb deformity, in diagnosis of Spigelian hernia, in siting of Lanz incision for appendicectomy or incision for stoma construction well above Arcuate line, in making incision for abdominoplasty/rectus abdominis myocutaneous flap harvest, in re-positioning of umbilicus after reconstructive/aesthetic surgery and in placement of middle port at or below the 
arcuate line during TEPP hernioplasty. However, the present observations may not be reliable in the obese patients. Validation of our results is recommended in Indian and NonIndian populations by more research work with larger sample size in clinical settings.

\section{REFERENCES}

[1] Ebnezar J (ed.). Clinical Examination Methods in Orthopedics (Supplement to Textbook of Orthopedics, $4^{\text {th }}$ Edition), $2^{\text {nd }}$ Edition, New Delhi: JAYPEE, 2010, p 68.

[2] Huger WE Jr. The anatomic rationale for abdominal lipectomy. Am Surg. 1979 Sep; 45(9): 612-617.

[3] Matarasso A. Liposuction as an adjunct to a full abdominoplasty revisited. Plast Reconstr Surg. 2000 Oct; 106(5): 1197-1202; discussion 12035.

[4] Davis MR, Talarcyzk MR. Anatomy and Topography of the Anterior Abdominal Wall. In: Melvin A. Shifman and Alberto Di Giuseppe (eds.) Body Contouring, Chapter 3, Berlin Heidelberg: Springer-Verlag, 2010, pp 27-31.DOI: 10.1007/978-3-642-02639-3_3.

[5] Al-Momani H, Miller C, Stephenson BM. Stoma siting and the 'arcuate line' of Douglas: might it be of relevance to later herniation? Colorectal Dis. 2014 Feb; 16(2):1413. DOI: 10.1111/codi.12469.

[6] Nigam VK, Nigam $S$ (eds.) Essentials of Abdominal Wall Hernias, Chapter 4, New Delhi: I. K. International Publishing House, 2008, pp 19-95.

[7] Powell BS, Voeller GR. Umbilical, Epigastric and Spigelian Hernia. In: Andrew N. Kingsnorth and Karl A. LeBlanc (eds.) Management of Abdominal Hernias, 4th Edition, Chapter 18, London: Springer, 2013, pp 299-308.

[8] Goyal S, Singla S. Spigelian HerniaDiagnostic Dilemma: Case Report with Review. Open Access Library Journal 2014; 1: e661. (http://dx.doi.org/10.4236/oalib.1100661)

[9] Ansari (2013): Ansari MM. Effective Rectus Sheath Canal: Does It Affect TEP Approach for Inguinal Mesh Hernioplasty. Journal of Experimental and Integrative Medicine (Turkey) 2013; 3(1): 73-76.

[10] Ansari (2015): Ansari MM. Arcuate Line Variations: Are they important for TEP surgeons? Kuwait Medical Journal 2015; 47: 313-316.

[11] Ansari (2017a): Ansari MM. Arcuate Line of Douglas: A Prospective Study of Laparoscopic Live Surgical Anatomy during TEPP Hernioplasty. Int J Sci Res 2017; 6(6): 23482363.
[12] Ansari (2017b): Ansari MM. Arcuate Line Position: Current Perspective and Revised Ansari Classification. Sci Fed J Surg 2017; (In Press).

[13] Ansari (2017c): Ansari MM. Posterior Rectus Sheath: A Prospective Study of Laparoscopic Live Surgical Anatomy during TEPP Hernioplasty. World J Lap Surg (In Press).

[14] Ansari (2017d): Ansari MM. Rectusial Fascia: A New Entity of Laparoscopic Live Surgical Anatomy. Open Access J Surg 2017 April; 3(4): Pages 5. DOI: 10.19080/ OAJS. 2017. 03.555618

[15] Deurenberg P, Weststrate JA, Seidell JC. Body mass index as a measure of fatness: age- and sex-specific prediction formulas. $\mathrm{Br} \mathrm{J}$ Nutr 1991; 65: 105-114.

[16] Ansari 2016: Ansari, MM. Thesis for PhD (Surgery) titled - "A Study of Laparoscopic Surgical Anatomy of Infraumbilical Posterior Rectus Sheath, Fascia Transversalis \& PrePeritoneal Fat/Fascia during TEPP Mesh Hernioplasty for Inguinal Hernia", Aligarh Muslim University, Aligarh, India, 2016

[17] Cunningham SC, Rosson GD, Lee RH, Williams JZ, Lustman CA, Goldberg NH, Silverman RP. Localization of the arcuate line from surface anatomic landmarks: a cadaveric study. Ann Plast Surg 2004; 53(2): 129-131.

[18] Loukas M, Myers C, Shah R, Tubbs RS, Wartmann C, Apaydin N, Betancor J, Jordan R. Arcuate line of the rectus sheath: clinical approach. Anat Sci Int 2008; 83(3): 140-144.

[19] Chouke KS. Anat Rec 1935; vol. LXI: p. 341.

[20] Walmsley R. The sheath of the rectus abdominis. J Anat 1937; 71: 404-414.

[21] Skandalakis P, Zoras O, Skandalakis J, Mirilas P. Spigelian hernia: Surgical anatomy, embryology and technique of repair. Am Surg 2006; 72: 42-72.

[22] Monkhouse, W. S. \& Khalique, A. Variations in the composition of the human rectus sheath: a study of the anterior abdominal wall. J. Anat., 145:61-6, 1986.

[23] Ombregt L (ed.) A System of Orthopaedic Medicine, eBook, Chapter 7, Philadelphia: Churchill Livingstone/Elsevier, 2009, p e246.

[24] Oster KA, Oster CA. Special needs population: Care of the geriatric patient population in the perioperative setting. AORN J 2015; 101: 44356; quiz 457-9.

[25] Tee JW, Rutges J, Marion T, Street J, Paquette S, Ailon T, Kwon BK, Dvarok M, Boyd M. Factors predictive of topographical accuracy in spine level localization. J Spine Surg 2017; 3(1): 23-30. DOI: 10.21037/JSS.2017.02.06 
[26] Sarkar PG. Spigelian hernia - a rare hernia: a case in a rare site. Int J Pharm Bio Sci 2013 Apr; 4(2): (B) $894-898$.

[27] Miletin J, Jochlik D, Hudak R, Volny O. Topography. In: Radovan Hudak, David Kochlik, Ondrej Volny et al (eds.) Memorix Anatomy, eBook, 1st Edition, Chapter 15, Plzenska (Czec Republic): Memorix S.R.O., 2015, p. 554.

[28] Delany, H.M., Carnevale, N.J. (1976): A "Bikini" incision for appendicectomy. American Journal of Surgery; 132(1): 126- 27.

[29] Pleterski, M., Temple, W.J. (1990): Bikini appendicectomy incision as an alternative to the McBurney approach for appendicitis. Canadian Journal of Surgery, 33(5): 343-345.

[30] Patnaik, VVG, Singla, RK, Bansal VK. Surgical incisions - their anatomical basis. J Anat. Soc. India 2001; 50(2): 170-178.

[31] Huger WE Jr. The anatomic rationale for abdominal lipectomy. Am Surg 1979; 45(9): 612-617.

[32] Matarasso A. Abdominoplasty. Clin Plast Surg. 1989 Apr; 16(2):289-303.

[33] Wallach SG, Matarasso A. Abdominolipoplasty: Classification and Patient Selection. In: Shiffman M.A., Mirrafati S. (eds) Aesthetic Surgery of the Abdominal Wall. Chapter 6, Berlin, Heidelberg: Springer, 2005, pp 70-86. DOI: 10.1007/3-540-27263-1_6

[34] Shiffman M.A. Avoiding Abdominal Wall Necrosis in Abdominoplasty. In: Shiffman M.A., Mirrafati S. (eds) Aesthetic Surgery of the Abdominal Wall. Chapter 17, BerlinHeidelberg: Springer, 2005, pp 155-159. DOI: 10.1007/3-540-27263-1_17

[35] Grevious MA. Abdominal Wall Reconstruction. http://emedicine. medscape. com/article/1297226. Last Updated Mar 04, 2016 (Accessed on Jul 6, 2017).

[36] Gutwein L. Abdominoplasty (Tummy Tuck) Part III-A lesson in Anatomy. February 18, 2017 (http:// www. grenadaplasticsurgery. com/ blog.html\#!/blog/posts/Abdominoplasty-

Tummy-Tuck-Part-IIIA-lesson-in-Anatomy/28) Accessed July 10, 2017.

[37] Cox WA. Traumatic injuries of the organs of the abdominal cavity: adult and pediatric. April 2012; pp 1-202. (https:// forensicmd. files. wordpress.com/2012/04/traumatic-injuries-ofthe-organs-of-the-abdominal-cavity-adult-andpediatric.pdf)

[38] Moore KL, Daily AF, Agur AMR (eds.) Clinically Oriented Anatomy. 7th Edition, Chapter 2, Philadelphia: Wolters Kluwer, 2014, pp 181-325.
[39] Chaurasia BD. Anterior Abdominal Wall. Slide Share Website (Accessed: July 12, 2017) (https://www.slideshare.net/jeffarian/anteriorabdominal-wall-bd-churasia)

[40] Kos J, Hert J, Hladikaova J (eds.) Survey of Topographical Anatomy. Chapter 4, Prague: Karolinum Press, 2014, pp 69-84.

[41] Duduković M, Kisić H, Baez ML, Bulić K, Veir Z, Cvjetičanin B, Dujmović A, Stipić I, Šuman O, Mijatović D. Anatomical Prediction for Surgical Positioning of the Umbilicus in a Croatian Population. Ann Plast Surg 2015 August; 75(2): 135-139.

[42] Mwachaka P, Odula P, Awori K, Kaisha. Variations in the Pattern of Formation of the Abdominis Rectus Muscle Sheath among Kenyans. Int J Morphol 2009; 27(4): 10251029.

[43] Mwachaka PM, Saidi HS, Odula PQ, Awori KO, Kaisha WO. Locating the arcuate line of Douglas: is it of surgical relevance. Clin Anat 2010; 23(1): 84-86.

[44] Anson BJ, Morgan EH, McVay CB. Surgical anatomy of the inguinal region based upon a study of 500 body halves. Surg Gynecol Obstet 1960; 111: 707-725.

[45] McVay CB. The anatomic basis for inguinal and femoral hernioplasty. Surg Gynecol Obstet 1974; 139: 931-945.

[46] Lange JF, Rooijens PPGM, Koppert S, Kleinrensink GJ. The preperitoneal tissue dilemma in totally extraperitoneal (TEP) laparoscopic hernia repair. Surg Endosc 2002; 16: 927-930.

[47] McVay CB, Anson BJ. Composition of the rectus sheath. The Anatomical Record 1940; 77(2): 213-225.

[48] Rizk NN. The arcuate line of the rectus sheathdoes it exist? J Anat 1991; 175:1-6.

[49] Lipa JE. Breast reconstruction with free flaps from the abdominal donor site: TRAM, DIEAP, and SIEA flaps. Clin Plast Surg. 2007 Jan; 34(1): 10521; abstract vii.

[50] Zenn M, May J. TRAM flap reconstruction. In: Spear S, ed. Surgery of the Breast: Principles and Art. Philadelphia: Lippincott-Raven; 1998:513.

[51] Katkhouda N. Advanced Laparoscopic Surgery: Techniques and Tips. 2nd Edition, Ch. 10, London: Springer, 1998, 149-168.

[52] Spitz JD, Arregui ME. Fascial anatomy of the inguinal region. In: Robert Bendavid, Jack Abrahamson, Maurice E. Arregui, Jean B. Flament, Edward H. Phillips (eds.) Abdominal Wall Hernias: Principles and Management, 1st Edition (Reprint), Chapter 8, Springer ScienceBusiness Media, New York, 2001, pp. 86-91. 
Interspinous Line: Relations with Other Landmarks (Xiphisternum, Umbilicus, Pubic Symphysis and Arcuate Line of Douglas) and Importance for Surgeons

[53] Meyer ALM, Bellandi DM, Delacoste F, Atger J, Berger E, Ranoya MAA, Monteiro O Jr, Alonso PA, Guimaraes LMM. Laparoscopic totally extraperitoneal inguinal hernia repair: Nonfixation of three-D mesh. Bras J VideoSurg 2010; 3(1): 019-023.

[54] Meyer A, Dulucq JL, Mahajna A. Laparoscopic totally extraperitoneal hernioplasty with Nonfixation of three-dimensional mesh dulucq's technique. ABCD Arq Bras Cir Dig 2013; 26(1):59-61.
[55] Mishra RK (ed.) Textbook of Practical Laparoscopic Surgery, 3rd Edition, Chapter 16, New Delhi: JAYPEE, 2013, pp 205-224.

[56] Iuamoto LR, Kato JM, Meyer A, Blanc P. Laparoscopic totally extraperitoneal (TEP) Hernioplasty using two trocars: anatomical Landmarks and surgical technique. ABCD Arq Bras Cir Dig 2015; 28(2): 121-123.

Citation: Maulana M. Ansari. Interspinous Line: Relations with Other Landmarks (Xiphisternum, Umbilicus, Pubic Symphysis and Arcuate Line of Douglas) and Importance for Surgeons. ARC Journal of Clinical Case Reports. 2017; 3(2):18-30. doi:dx.doi.org/ 10.20431 /2455-9806.0302005.

Copyright: (C) 2017 Authors. This is an open-access article distributed under the terms of the Creative Commons Attribution License, which permits unrestricted use, distribution, and reproduction in any medium, provided the original author and source are credited. 